\title{
The Comparative Political Economy of Collective Skill Formation
}

Marius R. Busemeyer and Christine Trampusch ${ }^{1}$

It is widely acknowledged that the availability of human capital contributes to economic performance and competiveness as well as social integration and equality. In recent years, the challenge of the globalized knowledge-based service economy prompted national governments and international organizations to pay increasing attention to skills. Policymakers regularly emphasize the need to invest in education and skill formation, but if human capital is such a desirable good, why is it so hard to create? And why do countries differ so much in how they attempt to produce it?

One of the most interesting conclusions of scholarly work in recent years is the insight that the development and availability of skills is not a matter of unconstrained, rational choices but is strongly conditioned by and reflected in the institutional context of political economies, both historically and in the contemporary period (Finegold and Soskice, 1988; Streeck, 1992a, 1996; Ashton and Green, 1996; Culpepper and Finegold, 1999; Hall and Soskice, 2001; Thelen, 2004, 2008; Cusack et al., 2007; Iversen and Stephens, 2008; Martin and Swank, 2008; Busemeyer, 2009a; Bosch and Charest, 2010; Trampusch, 2010a, 2010b). This literature also points out that "human capital" is not a homogenous good, but comes in different varieties and flavors, and that countries differ largely with regard to the availability of different kinds of human capital, which has important consequences for patterns of economic competitiveness and social integration.

Hence, the domain of skill formation must not be regarded in isolation from other domains of the political economy. The study of the politics and institutions of skill formation tells a lot about the development of political economies in general. Changes in the domain of skill formation 
have consequences for the development of adjacent spheres of the political economy, such as industrial relations, collective wage bargaining, the welfare state, and labor markets and vice versa. Instead of following a static approach and taking the existence of self-reinforcing equilibria for granted, this book emphasizes the dynamic, partly contingent, and fundamentally political nature of skill formation processes. Instead of viewing institutional arrangements of skill formation as the outcomes of rational and functional decisions of firms interested in minimizing transaction costs, the various contributions reveal skill systems to be institutions that are "fraught with tensions" (Mahoney and Thelen, 2010: 10) and always temporary and contested solutions to ongoing conflicts about the distribution of power.

More specifically, this volume is devoted to the study of collective skill formation systems, to be found in a number of countries usually depicted as "coordinated market economies." These systems have been admired by international observers and academic scholars alike, because they combine low levels of youth unemployment with high-quality occupational skills and thereby bolster the competitiveness of economies (e.g., Finegold and Soskice, 1988; Hall and Soskice, 2001). Following the inductive typical-case selection strategy (Gerring, 2007: 91), we selected Germany, Austria, Switzerland, the Netherlands, and Denmark as cases because they are representative of collective skill formation systems. As typical cases "serve an exploratory role" (Gerring, 2007: 91), the volume's main objective is to explore the historical and political origins of collective skill formation systems and how contemporary challenges condition their change.

The main characteristic of the vocational training systems of these countries is that they are collectively organized, because firms, intermediary associations, and the state cooperate in the process of skill formation in initial vocational training. In particular, this means that, first, firms are strongly involved in financing and administering workplace-based training; second, intermediary associations play an important role in the administration and reform of these systems; third, the systems provide portable, certified occupational skills; and fourth, training takes place not only in schools but also in companies, usually in the form of dual apprenticeship training.

There are three main insights linking the various chapters. The first insight is that collective skill formation systems are not self-sustaining institutional "equilibria." On the contrary, they are vulnerable and, in part, even fragile institutional arrangements that need the continuous political support of relevant stakeholders. The historical chapters in this volume provide the reader with a sense of the amount of contingency involved in the continual redesign of institutional arrangements and, in this sense, constitute a warning against attempts of ex post rationalizations. Confronted with contemporary challenges such as deindustrialization, Europeanization, and structural changes in the economy, collective training systems need to be adapted in order to 
The Comparative Political Economy of Collective Skill Formation

survive, but these processes of reform always entail the danger of transforming the defining character of the system (see Thelen and Busemeyer on Germany or Powell and Trampusch on international challenges, both in this volume). The second insight the book provides is that the variety of skill formation systems is largely conditioned by the decisions made on the division of labor between firms, associations, and the state in providing and financing skills. The third insight is that, in collective skill formation systems, these decisions are particularly contentious because the historical and contemporary development of collective skill formation systems is affected by political struggles during critical junctures with regard to four neuralgic points of conflict: the division of labor between the state, employers, their associations, and individuals on the provision (who provides?) and financing (who pays?) of vocational education and training (VET), the relationship between firm autonomy and public oversight in the provision of training (who controls?), and the linkages between VET and the general education system. The decisive causal factors that shaped political struggles over these points of conflict are, on the one hand, characteristics of firms and cleavages within the business camp ("logic of membership") and, on the other hand, characteristics of the state, unions, and the balance of power between business and labor ("logic of influence") (Schmitter and Streeck, 1999; Streeck and Schmitter, 1985).

The volume is divided into two sections. The first section-country studiescontains case studies on Germany (Kathleen Thelen, Marius R. Busemeyer), the Netherlands (Karen Anderson, Dennie Oude Nijhuis), Switzerland (Philipp Gonon, Markus Maurer), Austria (Lukas Graf, Lorenz Lassnigg, Justin Powell), and Denmark (Moira Nelson) and explores the historical origins and contemporary changes in collective skill formation systems. Preceding the country chapters, the chapter by Cathie Jo Martin revisits the crucial period of the formative phase of vocational training. On the basis of an in-depth study on Denmark, the United States, and Germany, Martin shows that partisan competition and the political features of state structures influence the organization of employers' associations and also their strategies in training policy. The second sectioncrosscutting topics and contemporary challenges-is directed more specifically at overarching topics currently discussed in the comparative political economy literature. It aims at discussing the interaction between deindustrialization, vocational training, and collective wage bargaining in determining stratification effects of training systems (Marius R. Busemeyer, Torben Iversen), the embeddedness of vocational training in educational systems (Rita Nikolai, Christian Ebner), the association between gender-related labor market stratification and vocational training (Margarita Estévez-Abe), and the impact of the Europeanization processes (Justin Powell, Christine Trampusch). In the foreword, Kathleen Thelen argues that capitalism cannot be discussed without addressing the topic of skills and critically reviews the studies conducted on 
this topic both inside and outside the Max Planck Institute for the Study of Societies. Wolfgang Streeck provides a concluding essay on the debate over general versus specific skills.

This introductory chapter is divided into five sections. In the first, we discuss the peculiarities of collective skill formation systems from the perspective of labor market economics and institutional political economy. On the basis of a typology of skill formation systems in advanced political economies, we highlight in the second section the central characteristics of collective training systems. The third section explores the variation within the group of collective skill formation systems, and the fourth discusses the political economy of collective skill formation, that is, the causal factors that shape the historical and current development. In the fifth section, we describe crosscutting topics and contemporary challenges, while again pointing to specific chapters of the book.

\section{Institutions and the economics of skill formation}

Labor market economists have struggled to explain the functioning of collective training systems (Harhoff and Kane, 1997; Acemoglu and Pischke, 1998, 1999; Wolter et al., 2006). From the perspective of standard human capital theory (Becker, 1993[1964]), the existence of collective skill systems poses several puzzles: why are firms willing to take over a significant share of the costs of initial VET despite the fact that apprentices are free to leave the firm after they complete their training? Why does a significant share of a typical youth cohort decide to pursue vocational training instead of academic higher education, a development that results in significantly lower student enrollment rates in countries with collective training systems compared with other nations (see Nikolai and Ebner in this volume)?

A partial answer to these questions lies in the role of institutions. Authors in the tradition of neo-institutional labor economics (Acemoglu and Pischke, 1998, 1999) explain the "irrational" willingness of firms to invest in skills as a result of "labor market imperfections." Because of low levels of labor turnover in countries such as Germany, so the argument goes, firms are more willing to invest in training, because there is a higher probability that apprentices will decide to stay with the training firm than in countries with flexible and fluid labor markets. Also, firms can use apprenticeship training as a gate-keeping device to internal labor markets, allowing them to identify candidates with "high potential" and to sort out the "lemons."

However, this kind of ex post rationalization of observed firm strategies in skill formation can, at best, provide partial answers only and, at worst, detract from the deeper lying causes of the diversity of skill regimes in advanced industrial democracies. For instance, Acemoglu and Pischke (1999) treat the 
existence of "labor market imperfections" as a given exogenous factor. They cannot (or do not aim to) explain the variation of labor market imperfections across country contexts. Therefore, their explanation for the continuing survival of collective training systems is partial at best, because it remains unclear whether firms themselves would be willing or able to create these imperfections as part of their skill formation strategies or whether they are caused by something exogenous to the economic process of human capital formation, that is, politics and society.

In contrast, scholarship in the tradition of institutional political economy (Streeck, 1992a, 1992b, 2009; Hall and Soskice, 2001; Thelen, 2004) pays close attention to the embeddedness of training institutions in a dense network of political and socioeconomic institutions, such as collective wage bargaining, corporate governance and financing, labor market and welfare state policies, as well as industrial relations. These accounts provide a clear answer as to the determinants of firm strategies in skill formation: the dense network of institutional constraints imposes "beneficial constraints" (Streeck, 1992a, 1994) on firms, encouraging them to invest in skills. Most importantly, the creation of "beneficial constraints" always entails an element of conflict between the different stakeholders, namely firms, workers, their associational representatives, and the state. The establishment of a collective institutional framework is not the result of a rationalistic process of deliberation among firms searching for the optimal skill formation strategy. Instead, training institutions have deep roots in the history of politics and society, which, in the case of apprenticeships, often go back to the Middle Ages (Thelen, 2004, $2007,2008)$. In short, this strand of literature argues that the preferences of actors in training are socially constructed and that it is the historical record which helps us to understand these preferences.

In line with these approaches, the contributions to this volume largely follow a historical-institutionalist perspective. The development of skill formation systems is regarded as a dynamic political process that unfolds according to empirically observable regularities; hence, it is possible to develop generalized propositions about these processes. At the same time, the development paths of skill formation systems are not predetermined, that is, there remains a significant amount of contingency, which is usually expressed in political struggles about institutional design and transformations. Thus, although training systems have deep historical roots, institutional arrangements different from the dominant pattern always remain latent options. Also, there is no inherent mechanism that guarantees the stability of these arrangements. Instead, institutions need the continual political support of important political stakeholders in order to survive in the long term (Thelen and Kume, 2006; Hall and Thelen, 2009). That said, the different chapters of this volume acknowledge the importance of critical junctures-tipping points in the historical 
development of political economies that open up contingencies that may (or may not) lead to the renegotiation of the institutional and political settlements of the past, while at the same time setting in motion a process of transforming the political arena for the next round of renegotiations in the future.

In the development of skill formation systems, we look at three critical junctures that set countries on specific trajectories and where fundamental decisions on the design of skill formation systems are renegotiated. Following Collier and Collier (1991: 29), we define a critical juncture "as a period of significant change, which typically occurs in distinct ways in different countries [...] and which is hypothesized to produce distinct legacies." In skill formation, the first critical juncture is located in the period of intensified industrialization and democratization at the end of the nineteenth and the beginning of the twentieth centuries, when the relative timing and sequence of the processes of state formation and industrial development decidedly shaped the industrial and political integration of business and labor as well as the formation of national labor markets. The second critical juncture lies in the 1960s and 1970s, when the postwar growth period came to an end. This period is associated with the rise of the neo-corporatist paradigm and the onset of the economic globalization. Finally, the current period of intensified economic and political globalization and the rise of the service and knowledge economy can be thought of as a third critical juncture, in which not only the deregulation of labor markets and the decentralization of industrial relations but also shifts in skill demands signal that a crucial transformation of contemporary political economies is underway.

\section{Varieties of skill formation systems}

Typologies necessarily imply a simplified picture of social reality. Nevertheless, they are useful tools for bringing order to complexity and for understanding processes of institutional change, in particular if they are designed in the Weberian sense of identifying ideal types that can help us make sense of the direction of change while showing us the alternatives that social actors have at their disposal. In the comparative literature on training, we find various typologies to distinguish national training systems, recognizing that the real guises of training systems also embody various elements of the different types (Finegold and Soskice, 1988; Blossfeld, 1992; Greinert, 1993; Lynch, 1994; Ryan, 2000; Crouch et al. (2004[1999])). This literature identifies several crucial dimensions of variation in the institutional design of training, such as the dominant venue of training, the degree of standardization and certification of skills, the degree of stratification and differentiation in the system of occupational degrees, the role of the state, and the linkages between skill formation and other 
The Comparative Political Economy of Collective Skill Formation

socioeconomic institutions such as the production system, industrial relations, and the welfare state.

In an early and by now classic contribution to the literature, Finegold and Soskice (1988) distinguish between the high-skill system of Germany and the low-skill system of the United Kingdom, emphasizing how the embeddedness of a firm's training decisions in a complex network of socioeconomic institutions shapes the incentives to invest in skill formation. According to Lymch (1994), the dominant venue of training is the most important dimension that sets systems apart from each other, for example, whether VET takes place at the workplace (Germany, Denmark) or in schools (France, Sweden). Blossfeld (1992: 172) adds to this dimension two others: the standardization and certification of skills as well as the stratification of vocational training.

Taking the paradox of collective action among firms as a starting point, Crouch et al. (2004[1999]: 25) stress the role of institutions in solving this problem (in line with Finegold and Soskice, 1988) and distinguish between three dominant forms of skill provision in initial vocational training: first, direct state involvement, where skills are provided in state-run and/or funded vocational schools and the role of employers is marginal (Sweden and France); second, corporatist networks, where employers' associations-"occasionally in association with trade unions" (Crouch et al. 2004[1999]: 27)-play an important role in the provision and administration of training (Germany); and third, markets, which lead to the dominance of on-the-job training (the United States).

Greinert (1993: 22-8) adopts an institutional approach as well, but in contrast to Crouch et al. (2004[1999]), he focuses on the role of the state in the process of skill provision and differentiates between the liberal model (the United States, the United Kingdom, Japan), the bureaucratic (school) model (France, Sweden, Italy), and the dual apprenticeship system (Germany, Switzerland, Austria).

Recently, skill systems have also gained prominence in the comparative literature on capitalism. In the seminal volume of Hall and Soskice on varieties of capitalism (VoC), skill systems are viewed as one of the five core socioeconomic institutions that distinguish liberal from coordinated market economies (Hall and Soskice, 2001) and are therefore responsible for specific strategies in national innovation policies and for the economic performance of countries. As is well known by now, the VoC literature also argues that institutional complementarities exist between skill formation systems and adjacent institutional spheres of the political economy and that these create mutual and beneficial interaction effects (Estévez-Abe et al., 2001; Iversen and Soskice, 2001, 2006; Thelen, 2004, 2008; Iversen, 2005, 2006; Cusack et al., 2007; Iversen and Stephens, 2008; Martin and Swank, 2008; Busemeyer, 2009a). 
Hall and Soskice (2001: 17) distinguish between two varieties of market economies associated with distinct skill formation systems. The crucial dimension in their typology is the specificity of skills the systems provide, namely general or specific skills. In liberal market economies (LMEs) such as the United States, the general education system, in particular higher education, provides generic human capital assets, which can then be complemented with on-the-job training in the firm. Coordinated market economies (CMEs) such as Germany, in contrast, place a strong emphasis on vocational training instead of and in addition to higher education. The combination of workplacebased training in the firm with theoretical education in vocational schools, often in the so-called dual apprenticeship programs, remains a viable alternative to academic or school-based education. Other contributions to the VoC literature go beyond this dichotomy by distinguishing between three types of skill specificity-firm-specific, industry- or occupation-specific, and general skills-and with it between three types of skill formation systems (Estévez-Abe et al., 2001).

These attempts of developing typologies of skill formation systems have several accomplishments to their credit. First, they have contributed enormously to our understanding of the variety of training regimes across countries. Second, the theories underpinning these typologies have also shown the crucial importance of the training behavior of firms for the dynamic political economy of skill formation systems. Third, they also made clear that firms' investments in skills strongly depend on "outside interference," for example, from employers' association or the state, into the financing and provision of training as well as the certification and standardization of skills. Fourth, the VoC approach has pointed out that skill formation affects the economic development of advanced political economies and is also affected by the evolution and development of other socioeconomic institutions.

Despite these merits, the existing literature has some deficiencies that we would like to address with this volume (see also the concluding chapter by Wolfgang Streeck). Examples of these deficiencies are the inability of the typologies to account for variations of skill formation systems within CMEs and also their inability to explain differences between countries with the same kind of skill formation system. The distinction between liberal and coordinated market economies or between general and specific skill systems is very broad and cannot account for different types of skill regimes within the separate clusters (Anderson and Hassel, 2007; Busemeyer, 2009a; Trampusch, $2010 a, 2010 b$ ). Also, the heterogeneity of the group of CMEs is much larger than it is for LMEs, as will be documented in greater detail below.

Furthermore, the VoC literature is less interested in understanding the political and historical origins of skill formation systems than in understanding their 
The Comparative Political Economy of Collective Skill Formation

effects on political economies. In the early contributions, the question of origins was explicitly excluded from the analysis (Estévez-Abe et al., 2001: 147; Hall and Soskice, 2001 passim). More recently, this has changed (Cusack et al., 2007; Iversen and Soskice, 2009; but see also Swenson, 2002; Mares, 2003). Nevertheless, some scholars (Jackson and Deeg, 2006; Bohle and Greskovits, 2009; Streeck, 2009, 2010) have criticized the static and functionalist character of the VoC approach. Without engaging in this debate here ${ }_{i}$ we second the point that the pertinent literature so far has not paid enough attention to the political and historical origins of skill formation systems (with some exceptions, of course, such as Thelen, 2004), in particular with regard to country cases that are not regularly discussed as "paradigmatic" examples, such as the ones covered in this volume. Also, because the VoC approach emphasizes the mutually reinforcing institutional complementarities of different "skills equilibria" (Finegold and Soskice, 1988; Hall and Soskice, 2001), its theoretical tools are less well developed when it comes to explaining the transformation and change of these systems.

What is the approach taken in this volume to make sense of the variety of skill formation systems? In what way are collective skill formation systems different from other models? Which factors explain the evolution of different skill formation systems?

In order to answer these questions, this volume follows a historicalinstitutionalist and firm-centered approach, which regards decisions on the division of labor between firms, associations, and the state in providing and financing skills as the core factor accounting for differences between different skill regimes in general as well as for differences within the group of the collective skill formation systems. In line with labor market economists and others (Hall and Soskice, 2001; Crouch et al. 2004[1999]: 25), we develop our argument by looking at the relationship between an individual firm and its institutional context and examining how these institutional arrangements of skill formation facilitate the solution of collective action problems typical of unregulated training markets. Starting from this baseline, it becomes clear that factors explaining the solution of collective action problems are also influential in shaping the development of different skill formation systems. According to theories on understanding employers' collective action (e.g. Schmitter and Streeck, 1999: 12; Martin and Swank, 2004; Martin, 2005), there are basically three reasons that motivate firms to cooperate: the regulation of competition between firms (in training in order to avoid poaching), the dynamics of class conflicts and labor mobilization, and state intervention in the economy. If we assume that these underlying forces (which are themselves affected by the major processes of industrialization, democratization, and labor market organization) explain why firms act collectively, the next question is which kind of institutional options employers have at their disposal in financing and providing skills. 
Building on the firm-centered perspective of the VoC approach and the work of Blossfeld (1992), Lynch (1994), and Crouch et al. (2004[1999]) and largely following Thelen (2007) and Busemeyer (2009a), we can distinguish between the liberal solution of narrow on-the-job-training, the segmentalist solution of self-regulation, the statist solution of state-run training, and finally, the collective solution where firms, associations, and the state collaborate in providing and financing skills.

On the basis of these considerations, we argue that there are two dimensions of variation that are helpful in describing the variety of skill regimes: the first dimension is the degree of firm involvement in the provision of initial vocational training. This dimension pertains to the willingness of firms to invest in skill formation, in particular initial vocational training. A higher involvement of firms in training might imply a higher specificity of training, but it is important to keep in mind that a strong commitment of firms to skill formation also means that firms are willing to invest in skills that are polyvalent and thus potentially transferable to other contexts (Streeck, 1996; Busemeyer, 2009a: 382; see also Streeck in this volume).

The second dimension is the degree of public commitment to vocational training (or more generally, the degree of state involvement in vocational training). This dimension captures various aspects: state subsidies to vocational training and public policies which monitor skill formation by certification and standardization and by formulating occupational training profiles. With this dimension, we also include the degree to which the institutional set-up of the educational system acknowledges and supports the existence of VET as a viable alternative to academic higher education.

In sum, we end up with a $2 \times 2$ matrix that captures the variety of training regimes (see Table 1.1). The two underlying dimensions can beoperationalized in different ways. The most common way found in the literature is to classify countries with the help of qualitative indicators (e.g., Aventur et al., 1999; Blossfeld, 1992; Ryan, 2000). These indicators capture characteristics of VET systems, for example, whether the educational system offers vocational in addition to academic degrees or whether an apprenticeship system exists or not. Quantitative indicators would allow a more fine-grained distinction between

Table 1.1 The variety of skill formation systems in advanced industrial democracies

\begin{tabular}{|c|c|c|c|}
\hline \multirow[t]{2}{*}{$\begin{array}{l}\text { Public commitment to } \\
\text { vocational training }\end{array}$} & \multirow{2}{*}{$\frac{\text { High }}{\text { Low }}$} & \multirow{2}{*}{$\begin{array}{l}\text { Statist skill formation } \\
\text { system (SW, FR) } \\
\text { Liberal skill formation } \\
\text { system (US, IR) }\end{array}$} & \multirow{2}{*}{$\begin{array}{l}\text { Collective skill formation } \\
\text { system }(\mathrm{GE}, \ldots \text { ) } \\
\begin{array}{l}\text { Segmentalist skill formation } \\
\text { system (JAP) }\end{array}\end{array}$} \\
\hline & & & \\
\hline & & Low & High \\
\hline & & \multicolumn{2}{|c|}{ Involvement of firms in initial vocational training } \\
\hline
\end{tabular}


education and training systems, but unfortunately, data availability is very limited. The Organisation for Economic Co-operation and Development (OECD) does not provide separate data for spending on VET, also because the distinction between vocational and general secondary education gets easily blurred and hinges on the specific characteristics of educational systems. Firm involvement is equally hard to measure. The OECD provides data on the share of upper secondary students in dual apprenticeship-like training schemes, but this operationalization neglects other kinds of firm involvement besides apprenticeship, such as firm-based training schemes (Japan) or employers offering workplacebased training in modules (the UK). The chapter by Busemeyer and Iversen provides more information on how to measure and operationalize these two dimensions and includes a scatterplot of countries, based on two quantitative indicators of firm involvement and public investment in VET (see Figure 8.1). For now, we introduce the reader to the different kinds of skill formation systems by referring to individual country cases.

In liberal skill formation systems, skill formation is largely provided through markets and in the general education system. In countries such as the United States, the general education system provides individuals with generic educational qualifications that are often complemented with internships and summer jobs during the phase of education and followed by more specific on-the-job training in the first stages of employment careers. Although high schools have vocational tracks (see Martin in this volume), their status is regarded as inferior in comparison with the academic tracks that prepare for admission to college. Vocational skills of higher quality are provided in community or vocational colleges, which have limited institutional linkages to the labor market and require students to pay tuition fees.

Japan is a prominent case of a segmentalist skill formation regime. In this country, the institutional setup of the general education system is quite similar to that in the United States (also because of the impact of the US occupation after World War II). The difference to the liberal skill regime is that the willingness of firms to invest in the formation of their employees' skills is much higher. A sizable share of a typical youth age cohort enters the internal labor markets of large firms immediately after leaving the general school system and subsequently undergoes an intensive process of skill formation that entails job rotation schemes and off-the-job training courses in in-house training centers and vocational schools.

The statist skill formation system is best exemplified by the Swedish or French educational system. In contrast to both the liberal and the segmentalist skill regimes, public policymakers are much more committed to supporting VET as a viable alternative to academic higher education in order to promote the integration of young people with weak academic qualifications into education and employment. In Sweden, this high level of commitment is also expressed 
through a systematic integration of vocational training with active labor market policies and further training. In order to promote educational mobility, VET is fully integrated into the general education system, which allows and encourages people with vocational qualifications to pursue tertiary education. As a corollary, the involvement of employers in the process of skill formation is very limited, although policymakers have repeatedly tried to expand the workplace-based components of vocational training, even in Sweden.

Finally, we highlight the characteristics of collective skill formation regimes, which are at the center of this book. Collective skill regimes occupy a special position in the comparison of skill regimes as they are characterized by a strong commitment of both the state and firms to invest in the formation of vocational skills. When we compare collective skill regimes with the other types, this distinctiveness becomes apparent because the dimensions of firm involvement and public commitment to training are often in conflict with each other. In the segmentalist skill regime, the high commitment of employers to skill investments goes along with a strong reluctance of the state to interfere in the training policies of firms. In the Scandinavian countries, the dominance of the political force of social democracy resulted in a strong public commitment to vocational training, which in turn contributed to the marginalization of the role of employers in initial vocational training (Nilsson, 2008). The collective training systems, however, combine strong involvement of firms in training and high public commitment of the state to support vocational training.

Fundamentally related to this cooperation between firms and the state are four characteristic particularities of collective training regimes. First, there is a high involvement of firms in the provision and administration of vocational training. Compared with other countries, a high share of firms is willing to shoulder a sizable burden of the cost of providing initial vocational educational training.

Second and related to this, intermediary associations such as employers' associations and-to a varying degree-trade unions play an important role in the administration and reform of collective training systems, which implies a specific division of labor between the state and associations. State actors refrain from intervening too much in the day-to-day organization of training and delegate important obligations to semi-public bodies such as chambers of industry and commerce or tripartite committees concerned with monitoring the implementation of training profiles and updating profiles to changing skill demands. Scholars have pointed out that these "private interest governments" (Streeck and Schmitter, 1985) are superior to state bureaucracies or market mechanisms in enforcing training standards, because they involve all major stakeholders. 
Third, the systems provide portable, certified occupational skills that are standardized and fully recognized on national labor markets. This means that the leeway of firms in determining the content of workplace-based training is limited by the necessity to confirm with national standards. However, the breadth and portability of occupational skills ensures union support of apprenticeship training, because the preservation of labor mobility is an important power resource for unions (Streeck, 1994). Also, at least some employers, in particular the small- and medium-sized firms, benefit from the existence of external occupational labor markets.

Fourth, VET takes place not only in schools but also in companies. This is usually done in dual training or apprenticeship schemes. These schemes combine practical learning at the workplace in the firm with theoretical education in vocational schools or colleges. The apprentice is not regarded as a student, but as a (paid) employee of the firm.

All of the countries covered in this book-Germany, the Netherlands, Denmark, Switzerland, and Austria-belong to the group of collective skill formation systems. Despite a number of commonalities, there are, of course, important differences between the individual country cases that have not yet been explored systematically. Instead of simply describing and cataloguing these differences, the authors of each country chapter delve into the political history of skill formation systems to explain the emergence of differences more fully. The country chapters document the political struggles over the design of institutional arrangements, which led to the formation of different development paths within the group of collective training systems. The authors structure their analyses using the scaffold of the three critical junctures we already mentioned: the evolution of training systems in the moment of industrialization, the tipping point of the 1960s and 1970s, and the intensified political and economic globalization with which we have been confronted since the mid-1990s. Essentially, what is at stake is the degree to which the interests of employers, the state, and (increasingly over time) the unions prevailed at specific moments in the development of training systems. In the following section, we present our account of a political economy of collective skill formation systems, which serves as a theoretical framework of explanatory factors for the country chapters.

\section{Varieties within the group of collective skill formation systems}

Conflicts about firm and state involvement are at the center of political struggles over the reform of VET systems, and in the group of collective skill formation systems; these conflicts have been solved in similar ways. In all of these systems, firms are more involved in the provision (and financing) of 
initial VET than in statist or liberal skill regimes, where the task of skill formation is either delegated to the state or to the market. Also, intermediary associations play a much stronger role in collective skill formation systems, a characteristic that sets them apart not only from the statist and liberal regimes but also from the segmentalist system.

From this it follows that, in contrast to the other skills regimes, the relationship between the autonomy of firms and the extensiveness of "outside interference" by associations or the state in collective skill formation regimes has historically been and remains at the core of the political struggles over reforming VET systems. The crucial point, and from a theoretical perspective the most interesting point, is that the extensive involvement of firms in the provision of initial vocational training depends on a particular combination of beneficial constraints and resources for collective action. In other words, maintaining the autonomy of firms to the largest extent possible does not contribute to the preservation of firm involvement in training because of the numerous collective action problems identified by labor market economists. At the other extreme, when the autonomy of firms in the provision of training is circumscribed too much by externally imposed constraints, employers' involvement in training is also not sustainable, as can be seen in the group of statist skill formation systems.

Over time, firms and individual employers can learn to turn constraints into resources. Being involved in the administration of collective training systems and cooperating with other employers and unions in processes of skill formation yields concrete benefits such as social peace and a highly trained, cooperative workforce, in particular for small and medium enterprises (SME) (see Martin in this volume). Collective self-regulation of employers in the form of "private interest governments" (Streeck and Schmitter, 1985) also bolsters organization building (i.e., of employers' associations), which helps to discipline unions and uncooperative employers.

Despite this, we maintain that training systems are fragile institutional arrangements and if the division of labor between firms, associations, and the state changes, regime shifts are possible. On the basis of the insights of the country chapters, we contend that conflicts about firm involvement and the role of the state in VET have regularly congealed around four neuralgic points of contention. These points are continuously contested and renegotiated in collective systems, whereas in the other skill regimes, they are less relevant as skill formation is more clearly delegated to the state, the market, or individual firms. The four neuralgic points are the relationship between firm autonomy and (semi-)public monitoring (who controls skill formation?), the relationship between firm-based and school-based vocational education and training (who provides skill formation?), the financing of skill formation (who pays for skill formation?), and the relationship between vocational education and training and the general education system. 
The Comparative Political Economy of Collective Skill Formation

The first neuralgic point is the relationship between firm autonomy and (semi-)public monitoring (who controls skill formation in the workplace?). In all collective training systems, the implementation and provision of training in firms is subject to some kind of public monitoring, meaning that firms and the state have to come to an agreement about the distribution of competences and responsibilities. The monitoring involves the processes of skill certification and standardization as well as the formulation of occupational profiles. The nature and extent of monitoring, however, differs significantly, which indicates various degrees of outside interference. The monitoring agencies can be tripartite bodies, equally representing the interests of trainees, vocational schools, and training firms (as in Denmark or Switzerland, depending on the cantonal legislation), or employer-dominated chambers of industry and commerce (as in Germany).

Furthermore, the extent of monitoring depends on the degree of detail in the regulation of recognized training occupations. As said above, training occupations are nationally recognized skill certificates in all collective skill formation systems, and the content of training profiles is devised in corporatist decisionmaking structures. However, countries differ largely with regard to the degree of flexibility granted to training firms in the implementation of training profiles. Whereas Swiss and Danish firms are more flexible (see Nelson in this volume; Wettstein and Gonon, 2009: 142), firms in Germany are required to follow detailed instructions and are closely monitored by the chambers and works councils. This difference in the flexibility of implementing training profiles and the more decentralized setting of apprentices' wages lead to lower training costs in Switzerland as compared with Germany, because Swiss firms are better able to employ apprentices as substitutes for semi-skilled labor (Wolter et al., 2006).

Another reason why the relationship between firm autonomy and (semi-)public monitoring is so contested is that large firms favor firm autonomy in certification. The chapter by Kathleen Thelen and Marius Busemeyer shows that the German skill formation system has recently changed from a strongly collective system to one in which skill formation fits the skill needs of large firms better than it does those of small and medium firms. The authors identify segmentalist tendencies not only in the certification but also in the standardization of skills as well as an increasing differentiation of occupational profiles. The chapter demonstrates that one cause of this development is the decentralization of the collective bargaining system, which has reduced the incentives that encourage firms to train in accordance with broad and uniform standards.

The second neuralgic point centers on the question "who provides skills?" and means the relationship between school-based and firm-based vocational education and training. Apprenticeship training always combines workplace-based 
training with theoretical education in vocational schools. However, countries differ with regard to the exact implementation of this division of labor between training firms and vocational schools within dual training schemes. More importantly, countries differ with regard to the importance of dual apprenticeship training relative to school-based VET. The latter plays the dominant role in countries such as Sweden and France, but, as the country chapters show, some cases within the group of collective skill formagation systems also have extensive school-based vocational education, primarily the Netherlands, but also Austria, the French-speaking part of Switzerland, and Denmark ${ }_{r}$ In Austria (as in Denmark and the Netherlands), the schoolbased pathway developed as a "legitimate alternative" to dual apprenticeship training, as a consequence both of the import of French ideas and of state intervention and private initiatives. The chapter by Graf, Lassnigg, and Powell shows that, historically, both pathways developed independent of each other and that the shape of the skill formation system in Austria was concretely influenced by the alternative of the French statist and bureaucratic schoolbased training system. Since the 1970s, the school-based training scheme has increasingly expanded, thereby pressuring the dual system to modernize. The school-based trajectory also expanded because many large, formerly public firms withdrew from apprenticeship training after they were privatized. As a consequence, only a relatively small proportion of the large Austrian industrial firms is engaged in apprenticeship training, which means that there is no social basis for segmentalism in Austria in comparison to Germany. Large firms are much more in favor of school-based training, whereas small firms remain committed to the dual system. In addition, large Austrian firms recruit skilled workers from foreign countries.

In the Netherlands (see Anderson and Oude Nijhuis in this volume), apprenticeship training remained underdeveloped until the 1980s unlike in all of the other countries examined in this book. This country started with a school-based vocational training system because of its late industrialization (and as a consequence of the late organization of business), the lack of artisanal associations as successors of the guilds, and the fact that firms and trade unions were not interested in using their engagement in vocational training as an organizational means in the period in which they were building their associations and creating the collective bargaining system. Historically, SME and Dutch unions preferred the school-based system because they could not coordinate apprenticeship. However, in the postwar period and particularly since the 1980s, apprenticeship training has become more important. On the one hand, this change occurred because public reform policies supported this trajectory. On the other, employers' associations and trade unions changed their strategies, became proactive stakeholders of apprenticeship, and incorporated the organization and financing of initial vocational training 
into collective bargaining agreements, for example by establishing sectoral training funds. We should note that social partners are also strongly involved in the management of the school-based system. In contrast to the Netherlands, in Denmark, Germany, Austria, and Switzerland strong trade associations followed more closely the model of the guild system. These associations were active in training, especially in apprenticeship, with the result that this pathway became the dominant training scheme from early on.

The third neuralgic point of conflict is the financing of initial vocational education and training. In the other skill regimes, the financing of VET is clearly delegated to the public purse in the statist system, the individual in the liberal regime, and firms in the segmentalist variety. In collective skill formation systems, however, costs for initial VET are shared by the state, employers, and individuals. Training firms usually shoulder the costs of the workplacebased components of apprenticeship training, whereas the state pays for vocational schools and the regulatory infrastructure. Individuals, as apprentices, contribute by accepting lower wages during the time of their training.

The exact division of costs among stakeholders varies across countries and time. Some countries, such as Denmark, the Netherlands, and Switzerland, have established redistributive schemes, which collect training levies from training and nontraining firms, for example, for apprentices' wages (see the various country chapters). In Germany, repeated attempts to introduce similar schemes have failed because of the strong and effective resistance by employers. Also, Austria and Denmark give out generous public subsidies to training firms in order to encourage participation in apprenticeship training, while in Germany employers oppose public subsidies for training, because they fear too much interference by state authorities.

The mix between school-based and firm-based training leads to the fourth neuralgic point of conflict: the relationship between vocational education and training and the general education system (see Nikolai and Ebner in this volume). This question is also related to the portability of vocational skills and the mobility of apprenticeship graduates across educational sectors. Historically, apprenticeship training was the responsibility of firms, meaning that it was regarded as the initial phase of employment, not education. Over time, as mentioned above, the state imposed constraints on the employer providing training and, as a corollary, institutional linkages between apprenticeship training and the general education system were established. In the Nordic statist skill formation systems, this process proceeded the furthest as reformers aimed at fully integrating vocational training into the general education system in order to promote educational and social mobility. In collective skill formation systems, the links between apprenticeship training and the general education system developed more tentatively. These linkages have 
two concrete manifestations: the ease of transition from compulsory secondary education to (post-)secondary training and the transition from training back to the (higher) education system.

Again, country differences are significant. Denmark, being a close neighbor to Sweden geographically and ideologically, provides for easy transitions from compulsory schooling to vocational training by having established a schoolbased alternative route that caters to those who were not successful in securing a training place (see Nelson in this volume). However, the permeability between vocational training and higher education is less developed than, for example, in Austria. Austria and Switzerland improved the permeability between apprenticeship training and higher education by introducing double qualifications that lead to vocational degrees and open up access to academic education (see Nikolai and Ebner in this volume). In Germany, the linkages between apprenticeship training and the general education system remain underdeveloped. Recently, the link between vocational training and higher education has become more and more important because of the Bologna Process and the EU initiative to create a European Qualifications Framework. As the chapter on Europeanization (by Powell and Trampusch) shows, both the introduction of bachelor (BA) degrees and the formulation of National Qualifications Frameworks (NQFs) put the stakeholders of vocational training systems under pressure to improve the permeability to higher education in order to maintain its attractiveness for school-leavers.

\section{Explaining variety: The political economy of collective skill formation}

As is documented in the country chapters, conflicts about the relative autonomy of training firms and the extensiveness of externally imposed constraints have regularly congealed along these four neuralgic points. But which factors explain the emergence of different trajectories within the group of collective skill formation systems?

In line with the historical-institutionalist tradition, we focus on the outcomes of political struggles between important stakeholders and relevant political actors in the continuous process of designing and redesigning the institutional frameworks of skill formation systems. By providing a brief preview of the findings of country chapters, we identify crucial actors and hypothesize on their interests and their role in the further development of training systems. In this, we adopt a contextual, historical perspective. This means that, rather thar assuming objectively definable economic interests, the chapters aim at documenting the empirically observable positions of actors and actor coalitions, for example, by relying on material from historical archives, secondary 
The Comparative Political Economy of Collective Skill Formation

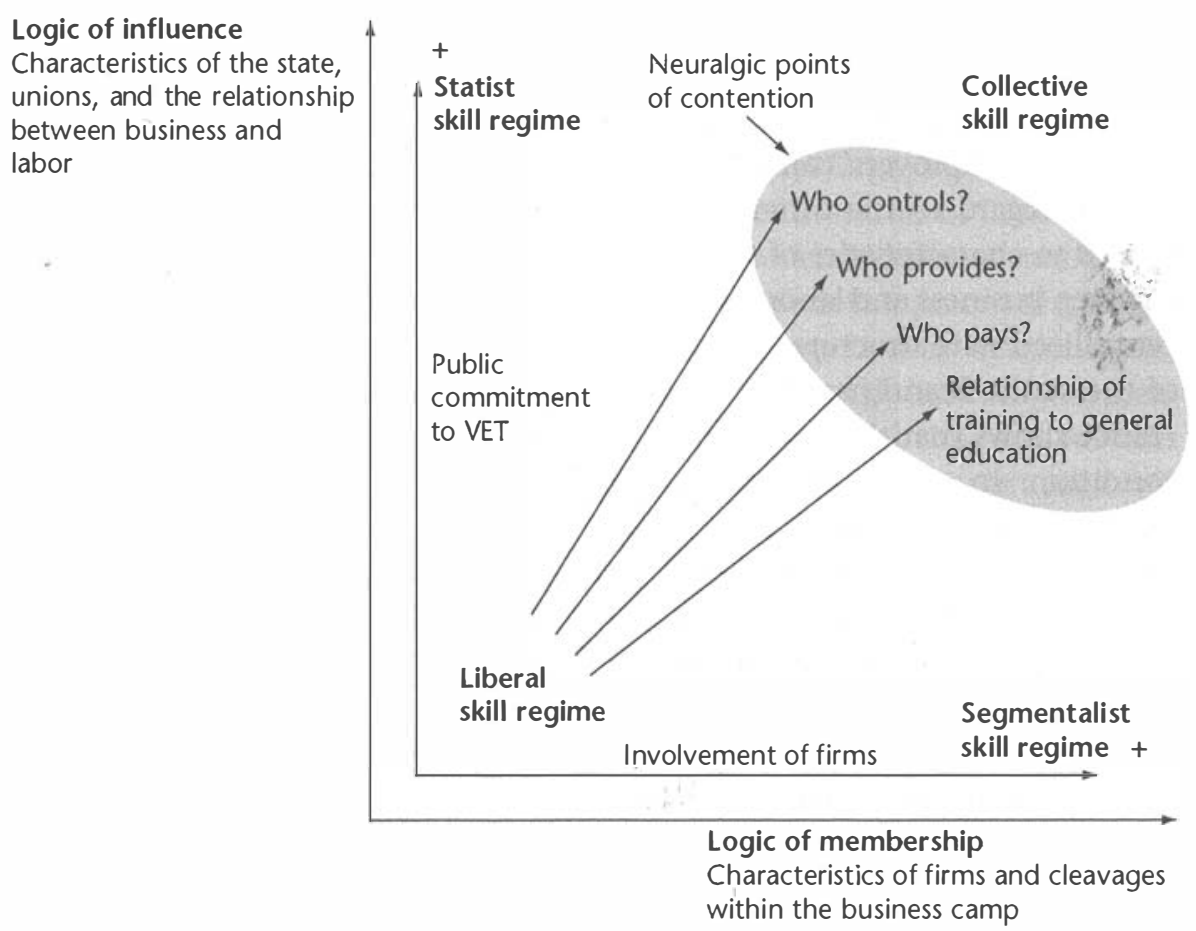

Figure 1.1 Explaining the variety of skill formation systems

literature, or interviews. Actors' positions may vary according to the specific context, also because actors adopt their preferences and political strategies in reflection of the outcomes of past struggles. Nevertheless, it is possible to identify overarching cleavages in the political economy despite the contextual character of preferences. We can use these cleavages to structure the discussion of political conflicts around the neuralgic points of contention identified above.

Coming back to our typology of skill formation systems from Table 1.1, Figure 1.1 illustrates our approach to explaining varieties within the group of collective skill formation systems. On the axes, we place the two dimensions of firm and state involvement that are also related to the four neuralgic points mentioned above, which lie at the core of political struggles over firm involvement and the role of the state in VET in collective skill formation systems.

Which causal factors determine the extent of firm and state involvement in VET? Firm involvement is largely influenced by the ability and willingness of firms and employers to coordinate with each other ("logic of membership," Schmitter and Streeck, 1999; Streeck and Schmitter, 1985). When coordination among employers is high, firms are more willing to invest in skills, because the danger of poaching is much reduced (Busemeyer, 2009a). Also, public and social obligations enforced by intermediary associations encourage 
firms to participate in collective schemes such as apprenticeship training. As a consequence, we argue, political conflicts about the extent of firm involvement in VET will largely be shaped by the characteristics of firms and cleavages within the employers' camp.

With regard to the other dimension, the extent of state involvement is related to characteristics of the state, trade unions, and the balance of power between business and labor ("logic of influence"). Powerful trade unions.and a centralized state structure have significantly contributed to the establishment of the statist Scandinavian model (Busemeyer, 2009a), although the case of France shows that the existence of powerful unions need not be a necessary condition. In collective skill formation systems, the cases of Austria and Denmark demonstrate how a unified and relatively powerful trade union movement in combination with a state structure that is more centralized than in the other collective skill formation regimes has contributed to the emergence of skill systems, in which the role of the state is more extensive than in Germany or Switzerland.

From this follows that there are four political arenas, in which political conflicts about the design of training institutions played out:

1. The characteristics of firms and the balance of power between different "fractions of capital" within the employers' camp ("logic of membership");

2. The power politics within the trade union camp;

3. The overall balance of power between business and labor;

4. The dynamic of partisan competition and state structures.

The latter three arenas belong to the "logic of influence."

First, given that employers play such a crucial role in the provision and implementation of vocational training, cleavages within the camp of employers have important consequences for the politics of vocational training reform. As Thelen (2004) has shown, the way the conflict over skill formation plays out between the industrial and the craft sectors puts skill formation systems on very different development paths. Historically, apprenticeship training is rooted in the crafts sector. At some point in the development of training systems, the question arose whether the craft-based model of skill formation should be extended to other sectors of the economy, should remain confined to the crafts sector, or should potentially wither along with the traditional organization of artisan trades. The latter happened in liberal countries such as the United Kingdom (Gospel, 1995), but not in the group of collective skill formation systems. Here, the question was more whether apprenticeship training would remain confined to the traditional sectors of the economy (as in Austria) or whether the industrial and crafts sectors would coordinate to develop a common framework for apprenticeship training with varying degrees of flexibility for the establishment of sector-specific institutional arrangements. 
All collective skill formation systems have found a way to coordinate different employers' interests via intermediary associations. But the specific outcome of this coordination of interests depends on the distribution of power between the industrial and the crafts sectors, between large firms and SME, as well as between the export-oriented and the domestic sectors of the economy (Culpepper, 2007; Trampusch, 2010a). On a fundamental level, therefore, the business structure of a political economy bears on the development of training systems. However, this association must not be regarded as deterministic, if only because there is a reciprocal causal relationship between business structure and skill formation as production strategies and thus the survival of certain types of firms depend on the availability of different kinds of human capital. Nevertheless, in countries dominated by SME (e.g., Austria and Denmark), apprenticeship training remained more closely tied to the traditional sectors of the economy (in particular in Austria). Instead of transferring the dual training model to the service sector, these countries expanded school-based vocational education to accommodate the new demand for different kinds of skills. Because of their mixed business structure, both the German and Swiss systems have long been characterized by tensions between different skill formation models, as the chapters by Thelen and Busemeyer and by Gonon and Maurer argue. Both chapters show that large firms were always in favor of more firm-based solutions, whereas the small and medium-sized firms clearly preferred the collective solution of dual apprenticeship. This can also be explained using the organizational interests of SME because their associations function as private interest governments in apprenticeship and any weakening of this training scheme would also lead to a weakening of their associations. Thelen and Busemeyer show that in Germany, at times when the interests of large firms in the export-oriented sectors of the economy prevail, the system is pulled in a "segmentalist" direction reminiscent of the skill formation strategies of Japanese corporations. At other times, the collective aspect dominates. Recently, segmentalist tendencies have also been observed in the Swiss commercial sector, where the large firms in the insurance and banking sector successfully lobbied for deregulating the training scheme (Trampusch, 2010c). Here, reforms since 1998 have lead to a weakening of the dual apprenticeship system because a degressive school model (meaning that school hours decrease in the second and third year of the apprenticeship) was introduced and the role of firms in the certification process was upgraded. In general, Switzerland is a case where a loose overarching institutional framework allows different sector-specific solutions to accommodate the different needs of crafts firms oriented toward the domestic market, on the one hand, and internationally active firms in the banking and insurance industry, on the other (Trampusch and Mach, 2011 passim). Also, the Netherlands show an interesting historical record which is different from 
the trajectories in Austria and Denmark. Here, SME preferred the school-based system over apprenticeship because they felt unable to coordinate the apprenticeship system (see Anderson and Oude Nijhuis in this volume).

Second, cleavages within the trade unions' camp matter as well. Historically, the distinction between crafts unions and industrial unions is crucial. Powerfúl crafts unions (again following in the footsteps of the guilds) used apprenticeship training to limit the access to skilled trades. As a consequence, the question of skill formation was contested across the class divide (Thelen, 2004), which then prompted employers to minimize their dependence on skilled labor and ultimately contributed to the decline of apprenticeship training, as happened in the United Kingdom. In contrast, strong industrial unions have been identified as important stakeholders in collective skill formation systems. However, it is necessary to emphasize that, in the initial stages of the development of these systems, the involvement of unions was actually quite limited and they were not necessarily in favor of dual training. For example, the Danish case study (Nelson) shows that general unions were more in favor of school-based training, whereas the craft unions defended apprenticeship. In contrast to Denmark, Austria, and Germany, the Swiss and Dutch trade unions were not proactively engaged in occupying this field in the formative phase of training systems (Trampusch, 2010b). This may be explained by the fact that, in Switzerland and the Netherlands, the collective bargaining system and the welfare state developed slowly, so that trade unions were far less integrated into the political and industrial relations system than in the other countries. The historical record also shows that Swiss and Dutch trade unions were more interested in using their involvement in the unemployment insurances, rather than the arena of vocational training, as a means to gain political and economic influence (Trampusch, 2010b). In short, we agree with Rothstein (1992) that the politics of skill formation and in particular the position of trade unions in training systems are decisively influenced by their logic of organization building.

Third, besides the conflicts within the respective camps, the overall balance of power between business and labor is central as well. Of course, this dynamic does not only vary across country contexts, but also over time. Employers defend their autonomy in the provision and implementation of training, whereas labor strives to impose external constraints. Employers prefer to invest in firm-specific skills, whereas industrial unions demand investments in polyvalent skills (Streeck, 1994, 1996) as well as the authoritative certification of these skills so that workers can also employ these in other firms. This conflict of interest about the scope and content of skills to be provided in firmbased training carries implications for the design of training institutions. Where (or when) business (particularly the camp of large firms) is strong, the imposition of external constraints is harder to achieve and vice versa. 
The Comparative Political Economy of Collective Skill Formation

However, as we are dealing with collective skill formation systems, the principal conflict between business and labor is mediated by a variety of institutional arrangements. The specific institutionalization of the class conflict in the structures of industrial relations bears on the shape of training institutions too. For example, in Denmark, collective agreements also regulated training from early on (Trampusch, 2010b). Furthermore, the chapter by Moira Nelson shows that (in addition to the social democratic party) the encompassing structure of the collective bargaining institutions strongly conditioned the development of the Danish training system. In the Netherlands in the 1980s, the polder model of consensual decision-making was also extended to the domain of training because employers' associations and trade unions cooperated in organizing and financing training by bipartite sectoral training funds.

Fourth, the state and political parties are decisive for two reasons. For one, the establishment of educational systems, be they oriented toward vocational training or general education, matters for processes of state formation. For another, the state and political actors intervene in social conflicts as partisan policymakers.

With regard to the first reason, historical work on the formation of training systems, which strongly refers to Stein Rokkan's reasoning on state development, provides very clear arguments why the state matters, predominantly in the early formative phase of educational systems (Green, 1990; Clarke and Winch, 2007: 11-12): First, the establishment of vocational training systems is intertwined with the formation of national labor markets and a national capitalist economic system. Second, governments not only seek to unify labor markets, but education and training are also important means to "develop a sense of national identity" (Clarke and Winch, 2007: 11) and citizenship.

With regard to the second reason, the role of the state in mediation and policymaking is related to its role in contemporary political economies. As Martin and Thelen (2007: 4) argue, the involvement of the state in CMEs is the "key to forging and sustaining broad national coalitions that link-rather than separate-diverse interests." Thus, the state plays a crucial role in supporting and managing coordination, and corporatist decision-making structures are integral elements of collective skill formation regimes. This, however, implies a conscious effort on the part of the state to delegate quasi-public obligations, such as the training of young persons, to business actors. The concrete shape of corporatist decision-making arenas depends in part on the balance of power between business and labor as well as between business associations and their membership. But the involvement of the state remains crucial. Confronted with these challenges, the state not only makes the fundamental decision to rely on hierarchical or consensual means of governance but can also design corporatist arenas by promoting the organization of weakly organized interests or by deliberately favoring one side over the 
other. The latter obviously depends on the political balance of power within the government system, meaning that government parties can play a crucial role by tipping the scales in favor of one policy solution or another. Whether parties are able to exert much influence depends on the institutional structure of the government system. In the Netherlands and Denmark, political power is centralized in the hands of the ruling majority, whereas the number of veto players is much higher in federalist systems, such as Germany. or in Switzerland with their hybrid political systems. In addition, political parties have different preferences on the dominant place of learning in VET. The chapters on Denmark (Nelson) and Austria (Graf, Lassnigg, and Powell) as well as the chapter on linkages to educational systems (Nikolai and Ebner) show that social democrats prefer school-based learning over company-based training, whereas Christian democrats are more in favor of the workplace (see also Busemeyer, 2009a). In Denmark, the social democrats failed to expand the role of school-based training because of the opposition from liberals, conservatives, and the social partners. In Austria, the importance of school-based vocational education can be traced to social democratic reform policies in the 1970s. However, we also have to note that, in general, party effects are less important in dual systems than in school-based regimes, because the role of the state is much stronger in the latter, which makes partisan politics matter more. In contrast, apprenticeship training is strongly influenced by the development of labor relations and is governed by corporatist policymaking. This point is nicely illustrated in the chapter of Graf, Lassnigg, and Powell on the Austrian case.

The chapter by Martin specifically focuses on how the political competition of parties and state structures shapes the formation of training systems. Martin makes several observations. First, she shows how the establishment of collective skill formation systems proceeded differently from processes in liberal systems by comparing Germany and Denmark, on the one hand, with the United States, on the other. Second, Martin also draws from the country chapters in the first part of this book to explain why Denmark developed in a different direction than Germany. She points to the importance of federalism and the structure of the party system as explanatory factors. Two-party systems, as in the United States, lack a dedicated business party, which forces business actors to engage with both major parties and thus compete with various other constituencies. This, in conjunction with decentralized political and economic systems, in turn, makes coordinated approaches to skill formation less likely to succeed. In proportional representation (PR) systems, business actors are more likely to be able to work with a dedicated business party (such as the conservative Højre party in Denmark). This facilitates the coordination among employers and bolsters the establishment of encompassing employers' associations, whom Martin identifies as important 
stabilizers of collective skill formation regimes. Because of strong federalism and regional heterogeneity, the coordination among employers in Germany was far less tight-knit than in Denmark. Whereas Germany's northern neighbor was able to coordinate on the macrolevel, meso-level coordination of the industrial sector, the region, or both was most effective in Germany, which also maintained a strong firm-based component. These differences in the setup of political institutions can explain why Germany has developed into a more heterogeneous system at times fraught with internal tensions between different training models, as described in the chapter by Thelen and Busemeyer.

Summing up, we identify four neuralgic points of conflict over the design of training institutions: the relationship between firm autonomy and public monitoring, the relationship between firm-based and school-based VET, the financing issue, and the relationship between vocational training and the general education system. Furthermore, building on the differentiation between the logic of membership and the logic of influence, we argue that the politics of collective training systems are determined by the specific shape of cleavages and their representation via intermediary associations within the employers' and trade unions' camps, respectively, by the overall balance of power between business and labor, and by the dynamic of partisan competition and state structures. Thus, different "settings" in these political and institutional variables during specific periods of time can explain the emergence of different trajectories within the group of collective skill formation systems.

\section{Crosscutting topics and common challenges to collective skill formation systems}

Despite the differences indicated above and to be explored further in the country chapters, there are a number of common challenges that collective skill formation systems are facing. Some of these challenges-such as structural change in the economy and globalization-affect all developed democracies, while others are more specific to the group of countries covered by this volume. Also, policy reactions in the countries to these common challenges naturally differ, as will be explored in the country chapters. But, when comparing collective skill formation systems, we also find commonalities which are linked to the specific institutional characteristics of these systems. The issue of varieties and commonalities of collective skill formation systems lies at the center of the second part of this book, whose chapters deal with crosscutting topics, such as how the interaction between vocational training and collective wage bargaining shapes the impact of deindustrialization on labor market stratification (Busemeyer and Iversen), the linkages between training and the general 
education system, in particular higher education (Nikolai and Ebner), the association between gender-related labor market stratification and vocational training (Estévez-Abe), and the impact of the European Union on change in collective training systems (Powell and Trampusch). Coming from slightly different angles and relying on different frameworks of comparison, the chapters all essentially deal with the question of how collective skill formation systems differ from each other and from other types of skill formation systems as well as how they react differently to common challenges.

\section{From the industrial to the service and knowledge economy}

Without question, structural changes in the economy have far-reaching consequences for the development of skill formation systems. Vocational training, in particular in the form of dual training, is deeply connected to the industrial economy. Therefore, it can be surmised that collective skill formation systems are affected by and interact with the forces of deindustrialization in ways different from those of other skill systems. The literature provides different perspectives on the impact of deindustrialization in collective skill formation systems.

For one, the rise of the service sector and associated changes in the skill demands of firms have repeatedly been identified as important factors contributing to the secular retreat of firms from offering apprenticeship training (see Busemeyer, 2009b: 62ff. for details). Whereas practical talents and manual work are valued in an industrial setting, social and management skills as well as more theoretical knowledge are more important in service-sector occupations. However, these kinds of skills are often better provided in a school-based setting or through on-the-job learning rather than in the form of dual training, which can then be regarded as either too expensive or not theoretical enough. Thus, it has been argued that the prevalence of dual training limits the ability of economies to adjust to the needs of the service economy (Anderson and Hassel, 2007), results in less job growth and fewer opportunities for young people to develop their human capital, and, as a consequence, increases labor market stratification and inequality. From this more pessimistic perspective, we could then expect a further retreat of firms from offering vocational training places as a consequence of ongoing deindustrialization and, at the same time, a failure of collective skill formation systems to make full use of the potentials for job creation and growth expected from the rise of the service and knowledge economy.

A different, more optimistic perspective is provided in the VoC literature (Estévez-Abe et al., 2001; Hall and Soskice, 2001) and its predecessors (Streeck, 1992a, 1994, 1996). Here, the prevalence of collective forms of skill formation is regarded as a major asset of CMEs, contributing to the continued 
competitiveness of manufacturing firms in the production of high-quality products on world markets. The fact that the industrial sector continues to be larger in countries such as Germany and Switzerland is thus not regarded as a failure to adapt to the needs of the service economy, but as a sign of the continued strength of the manufacturing industry in these countries, for which the availability of dual vocational training plays an important role. Furthermore, the fact that the educational system offers different opportunities for young people with different talents is regarded as a positive factor contributing to lower levels of labor market inequality (Estévez-Abe et al., 2001) and smooth transitions from school to employment, which results in low levels of youth unemployment (Allmendinger, 1989; Gangl, 2003). In countries without viable vocational training, such as the United States, young people who do not make it to college are faced with very low wages and high levels of employment insecurity. In contrast, in collective skill formation systems, so the argument goes, young people with more "practical" talents have the option of pursuing vocational training, which then leads to well-paid employment as a skilled worker.

The chapter by Busemeyer and Iversen addresses these seemingly contradictory findings in the literature by looking at the question of how different kinds of training institutions, in interaction with collective wage bargaining arrangements, shape the impact of deindustrialization on labor market stratification. In particular, the authors find evidence for a strong interaction effect between training institutions and the centralization of collective wage bargaining. High levels of firm involvement in training or a strong public commitment to VET has a negative impact on different measures of labor market stratification, such as wage dispersion and youth unemployment, only when the centralization of wage bargaining is also at high levels. For medium levels of wage bargaining centralization, the dominance of firm-based training actually enhances labor market stratification because it raises the hurdles for outsiders to get access to training. From a different perspective, the chapter also shows that there is no inherent institutional complementarity between vocational training and wage bargaining centralization. Certainly, dual training schemes need to be embedded in a corporatist institutional framework in order to encourage the willingness of firms to participate in training, but the exact shape of theses institutional arrangements is not foreordained and can be associated with very different labor market outcomes.

\section{Academic drift}

Besides labor market stratification, another trend that is commonly associated with the structural transformation from the industrial to the service economy is the rising demand for high-level academic skills. This holds true on the part of both employers as well as young people who are facing educational choices. 
With rising educational aspirations and the abolishment of barriers blocking access to higher educational institutions, the expansion of student enrollment rates has been one of the few megatrends encompassing all advanced industrial democracies (Stevens et al., 2008). In the group of collective skill formation systems, this trend was less pronounced than in countries with other kinds of skill systems (see the chapter by Nikolai and Ebner for more detailed data). Possible explanations for this abound. For one, the democratization of access to higher education is hindered in more "conservative" educational systems like those found in the German-speaking countries that are characterized by stratified secondary school systems with the early tracking of pupils into different academic and vocational streams (Powell and Solga, 2011). For another, the wage premium of university education might be lower in systems with strong vocational training tracks, encouraging more people to decide in favor of vocational training instead of higher education. Although "academic drift" might be less pronounced than in other types of systems, overall it remains a significant trend even in collective skill formation systems, challenging them in particular ways.

One of these challenges evolves from the possibility that employers in need of workers with high-level theoretical skills might increasingly realize the limits of VET in producing these skills. Rather than investing in dual training schemes, firms could pursue alternative training models, such as hiring school-leavers with strong academic skills and then investing in onthe-job training, or firms could develop new, flexible combinations between university education and workplace-based training (the so-called dual study programs) as is done in Germany (Bosch, 2010). Another challenge facing collective skill formation systems is that young people are increasingly reluctant to pursue vocational training, because a certificate from an institution of higher education increasingly seems to be a better insurance against labor market risks. Levels of unemployment are lower for higher-education graduates, and wages are higher even in collective skill formation systems.

The crucial takeaway from these developments is that the expansion of access to higher education contributes to an erosion of vocational training "from the top." Whereas before, the median person in the distribution of skills would have opted for vocational training, this person now tends to favor higher education. This has consequences for the firms' decisions to invest in training: in times when access to higher education was limited to a minority, firms had no problems recruiting well-qualified school-leavers for the vocational training route. Yet, as a greater share of the better-qualified school-leavers opt for university education, the composition of the pool of apprenticeship applicants changes. Instead of providing a heterogeneous mix in terms of academic skills and practical talents, the pool of apprenticeship applicants increasingly consists of young people with low educational 
qualifications who do not have the option to pursue higher education. As firms increasingly complain about the lack of "trainability" (Ausbildungsreife), their preference for higher-education graduates and their reluctance to invest in vocational training are reinforced.

However, as is shown in the chapter by Nikolai and Ebner, collective skill formation systems do not simply expand access to institutions of higher education, for example, by increasing the number of study places at public universities. The availability of high-quality vocational training has encouraged firms to pursue particular production strategies (Hall and Soskice, 2001; Streeck, 1992a) in high-quality niches of the world market. Therefore, firms and other stakeholders in the system would like to preserve the strengths of vocational training while enriching its theoretical content. Improving the permeability between vocational training and higher education is also a strategy to maintain the attractiveness of VET for school-leavers with good qualifications. Nikolai and Ebner document recent reforms that improve the embeddedness of vocational training in the general education system in the German-speaking countries, which have traditionally exhibited exceptionally low levels of educational mobility from vocational to higher education. The authors show that Austria and Switzerland have enacted institutional reforms to open up access to the higher-education sector for persons with vocational qualifications. In Germany, however, no serious reforms have come to pass. According to Nikolai and Ebner, this outcome is due to the fact that in Germany a significant share of graduates from the academic track of secondary education decides to pursue vocational training instead of higher education. On the one hand, this is strong evidence for the continued attractiveness of the German dual system. On the other, it reduces the political pressure for opening up access to higher education for graduates of the vocational training system, who still face high hurdles in order to access university education, while people with academic qualifications can freely choose to attend a university after training.

\section{Gender issues}

As part of deindustrialization and the expansion of access to higher levels of education, female labor market participation has increased significantly-in line with women's rising levels of educational attainment. Again, this trend encompasses all the countries of the industrialized world, but collective skill formation systems are challenged in particular ways. Estévez-Abe shows in her chapter that the dominance of dual apprenticeship training in collective skill formation systems poses obstacles for women (see also Estévez-Abe, 2005,2006 ). Because dual training aims at the formation of occupational skills, young women are more reluctant to commit to this type of training, because it implies higher risks of becoming (and staying) unemployed after 
family-induced breaks in the employment career. Similarly, Estévez-Abe argues, employers in collective skill formation systems are more reluctant to recruit women for vocational training, because they fear the loss of the skill investment should women decide to leave the labor force. Above and beyond the economic cost-benefit calculus of skill investments, culture and the institutions of the conservative welfare model associated with most of the countries covered in this book have certainly played an important role in slowing down the expansion of female labor-force participation. However, Estévez-Abe also makes clear that there are important differences within the collective skill formation system. Comparing Denmark with Germany, Estévez-Abe argues that the greater emphasis of school-based training in Denmark reduces the gender bias in vocational training.

However, as in the case of academic expansion, the trend of increasing female labor force participation is still present in collective skill formation systems. In the long term, it might contribute to transformative shifts in the makeup of these training systems. In Germany, for example, rising levels of educational attainment and women's preference for service-oriented occupations contribute to a development that enhances the labor market position of young women working in the expanding social, educational, and health sectors. However, young men with a low level of school qualifications are having a harder time getting access to vocational training as firms become more reluctant to hire apprentices, leaving these young men often limited to the less attractive and more insecure craft sectors of the economy.

\section{Europeanization}

Finally, a fourth megatrend in industrialized economies is the internationalization of economies. The process of globalization has many facets, some of which are more relevant in the present context than others. In the field of education, scholars have observed a significant increase in the importance of international organizations such as the OECD or UNESCO in policymaking (Jakobi and Martens, 2007; Walkenhorst, 2008; Powell and Solga, 2010). More important for the context of this edited volume is the Europeanization of education policy. Although a specific prohibition of harmonizing the educational systems of member states was introduced in the Treaty of Maastricht in 1992, the European level of decision-making has become an important driving force of national reforms. The Bologna Process instigating reforms in the higher-education sector is the prominent example. But the field of vocational training is also affected, as is shown in the chapter by Powell and Trampusch. Moreover, this process is not restricted to the member states of the European Union, as countries such as Switzerland demonstrate (Gonon, 1998; Bieber, 2010; Trampusch, 2010c). 
As in the other domains, collective skill formation systems are affected by the process of Europeanization in specific ways. The EU is still formally prohibited from harmonizing educational systems. Therefore, EU policymakers resort to "soft" modes of governance such as the open method of coordination $(\mathrm{OMC})$, recommendations, or guidelines.

The policy instruments that are developed, such as the European Qualifications Framework (EQF) or the European Credit System for Vocational Edưcation and Training (ECVET), aim to improve the comparability of educational qualifications-not their harmonization-and the mobility of students and apprentices. However, in some respects they are at odds with the normative and political logic underpinning collective skill formation systems (Trampusch, 2009). In these countries, vocational training is organized around the notion of an "occupation" (Berufsprinzip). This implies a certain detachment of the process of skill formation from the immediate needs of the labor market and the training firm. The skills that are provided in dual training entail a firmspecific component, but they are aimed at broader occupational categories and portable across a range of firms (Estévez-Abe et al., 2001; Busemeyer, 2009a; see also the concluding chapter by Streeck). In contrast, EQF and ECVET aim at defining individual training modules that can be flexibly combined and that, in sum, can define the skill portfolio of the respective person. Some critics claim (see Busemeyer, 2009b: 166-9) that the formation of occupational skills cannot be neatly compartmentalized into singular training modules. Instead, training has to be integrated with the working process. This perspective finds resonance with the political interests of the trade unions, who fear that firms could use the module system to stop offering comprehensive training and start to "pick and choose" the training package that fits their needs best (and usually falls short of the formerly comprehensive training occupations). The chapter by Powell and Trampusch analyses how these political conflicts about the nature and scope of Europeanization have played out in the countries with collective skill formation systems.

In his concluding essay, Wolfgang Streeck critically reflects on the distinction between general and specific skills and provides a more comprehensive analytical framework for classifying types of skills. Touching on a number of topics discussed at length in the individual chapters, Streeck also discusses the impact of politics and history on the development of skill formation systems.

\section{Conclusion}

This introductory chapter has elaborated on the concept of collective skill formation systems. We have shown how and why this group of skill formation systems occupies a special place in international comparison. In contrast to 
statist, liberal, or segmentalist systems, responsibilities for skill formation are not clearly delegated to the state, the market, or individual firms, but shared between the relevant stakeholders. This regularly leads to conflictual renegotiations and transformations of institutional arrangements-processes that are only partly controllable by state authorities because labor market actors and their associations play an important role in the administration and reform of collective skill formation systems. Thus, processes of institutional change in collective skill formation systems provide insights into the general dynamics of these political economies, reaching beyond the narrow sphere of vocational training. The purpose of this book is to document and explain institutional change in collective skill formation systems in the historical and contemporary periods and to promote our understanding of the institutional linkages between training, labor markets, collective wage bargaining, and political institutions.

\section{Endnote}

1. We would like to thank Klaus Armingeon, Cathie Jo Martin, and Justin J.W. Powell for their detailed comments. Many of the ideas presented in this chapter have evolved during continuous discussions with Kathy Thelen and Wolfgang Streeck. We would also like to thank the participants of the book conference at Cologne in May 2010 for invaluable feedback and input.

\section{References}

Acemoglu, D. and Pischke, J.-S. (1998). "Why Do Firms Train? Theory and Evidence." Quarterly Journal of Economics 113(1): 79-119.

(1999). "Beyond Becker: Training in Imperfect Labour Markets." Economic Journal 109(453): F112-42.

Allmendinger, J. (1989). "Educational Systems and Labour Market Outcome." European Sociological Review 5(3): 231-50.

Anderson, K.M. and Hassel, A. (2007). Pathways of Change in CMEs: Training Regimes in Germany and the Netherlands. Paper prepared for the American Political Science Association Meeting, Chicago, IL.

Ashton, D. and Green, F. (1996). Education, Training and the Global Economy. Cheltenham, UK: Edward Elgar.

Aventur, F., Campo, C. and Möbus, M. (1999). "Factors in the Spread of Continuing Training in the European Community." Cereq Training \& Employment 1998(35): 3-6. Becker, G.S. (1993)[1964]. Human Capital: A Theoretical and Empirical Analysis with Special Reference to Education. Chicago: University of Chicago Press. 
Bieber, T. (2010). "Europe à la Carte? Swiss Convergence towards European Policy Models in Higher Education and Vocational Education and Training." In M.R. Busemeyer and C. Trampusch, eds., Berufsbildungs- und Hochschulpolitik in der Schweiz, Österreich und Deutschland. Special issue Swiss Political Science Review 16(4): 773-800.

Blossfeld, H.-P. (1992). "Is the German Dual System a Model for a Modern Vocational Training System?" International Journal of Comparative Sociology 33(3-4): 168-81.

Bohle, D. and Greskovits, B. (2009). "Varieties of Capitalism and Capitalism 'tout court.'" Archives Européennes de Sociologie 50(3): 355-68.

Bosch, G. (2010). "The Revitalization of the Dual System of Vocational Training in Germany." In G. Bosch and J. Charest, eds., Vocational Training: International Perspectives. New York: Routledge, 136-61.

C Charest, J. (2010). Vocational Training: International Perspectives. New York: Routledge.

Busemeyer, M.R. (2009a). "Asset Specificity, Institutional Complementarities and the Variety of Skill Regimes in Coordinated Market Economies." Socio-Economic Review 7(3): 375-406.

- (2009b). Wandel trotz Reformstau: Die Politik der beruflichen Bildung seit 1970. Frankfurt a.M. Campus.

Clarke, L. and Winch, C. (2007). "Introduction." In L. Clarke and C. Winch, eds., Vocational Education: International. Approaches, Developments and Systems. London: Routledge, 1-17.

Collier, R.B. and Collier, D. (1991). Shaping the Political Agenda: Critical Junctures, the Labor Movement, and Regime Dynamics in Latin America. Princeton: Princeton University Press.

Crouch, C., Finegold, D. and Sako, M. (1999). Are Skills the Answer? The Political Economy of Skill Creation in Advanced Industrial Countries. Oxford: Oxford University Press.

Culpepper, P.D. (2007). "Small States and Skill Specificity: Austria, Switzerland, and Interemployer Cleavages in Coordinated Capitalism." Comparative Political Studies 40 (6): $611-37$.

— Finegold, D., eds. (2004)[1999]. The German Skills Machine: Sustaining Comparative Advantage in a Global Economy. New York: Berghahn Books.

Cusack, T.R., Iversen, T. and Soskice, D. (2007). "Economic Interests and the Origins of Electoral Systems." American Political Science Review 101(3): 373-91.

Estévez-Abe, M. (2005). "Gender Bias in Skills and Social Policies: The Varieties of Capitalism Perspective on Sex Segregation." Social Politics: International Studies in Gender, State and Society 12(2): 180-215.

- (2006). "Gendering the Varieties of Capitalism: A Study of Occupational Segregation by Sex in Advanced Industrial Societies." World Politics 59(1): 142-75.

— Iversen, T. and Soskice, D. (2001). "Social Protection and the Formation of Skills." In P.A. Hall and D. Soskice, eds., Varieties of Capitalism: The Institutional Foundations of Comparative Advantage. Oxford and New York: Oxford University Press, 145-83.

Finegold, D. and Soskice, D. (1988). "The Failure of Training in Britain: Analysis and Prescription." Oxford Review of Economic Policy 4(3): 21-53.

Gangl, M. (2003). "The Structure of Labour Market Entry in Europe: A Typological Analysis." In W. Müller and M. Gangl, eds., Transitions from Education to Work in 


\section{The Political Economy of Collective Skill Formation}

Europe: The Integration of Youth into EU Labour Markets. Oxford: Oxford University Press, 107-28.

Gerring, J. (2007). Case Study Research: Principles and Practices. Cambridge: Cambridge University Press.

Gonon, P. (1998). Das internationale Argument in der Bildungsreform: Die Rolle internationaler Bezüge in den bildungspolitischen Debatten zur schweizerischen Berufsbildung und zur englischen Reform der Sekundarstufe II. Berne: Peter Lang.

Gospel, H.F. (1995). "The Decline of Apprenticeship Training in Britain." Industrial Relations Journal 26(1): 32-44.

Green, A. (1990). Education and State Formation: The Rise of Education Systems in England, France and the USA. Houndmills: Palgrave.

Greinert, W.-D. (1993). Das "deutsche System" der Berufsausbildung: Geschichte, Organisation, Perspektiven. Studien zur Vergleichenden Berufspädagogik. Baden-Baden: Nomos.

Hall, P.A. and Soskice, D. (2001). "An Introduction to Varieties of Capitalism." In P.A. Hall and D. Soskice, eds., Varieties of Capitalism: The Institutional Foundations of Comparative Advantage. Oxford: Oxford University Press, 1-68.

- Thelen, K. (2009). "Institutional Change in Varieties of Capitalism." SocioEconomic Review 7(1): 7-34.

Harhoff, D. and Kane, T.J. (1997). "Is the German Apprenticeship System a Panacea for the US Labor Market?" Journal of Population Economics 10(2): 171-96.

Iversen, T. (2005). Capitalism, Democracy, and Welfare. Cambridge: Cambridge University Press.

- (2006). "Responses and Some Agenda Items for the Future Study of Democratic Capitalism." Labor History 47(3): 439-49.

- Soskice, D. (2001). "An Asset Theory of Social Policy Preferences." American Political Science Review 95(4): 875-93.

_ (2006). "Electoral Institutions and the Politics of Coalitions: Why Some Democracies Redistribute More than Others." American Political Science Review 100 (2): $165-81$.

_ (2009). "Distribution and Redistribution: The Shadow of the Nineteenth Century." World Politics 61(3): 438-86.

— Stephens, J.D. (2008). "Partisan Politics, the Welfare State, and Three Worlds of Human Capital Formation." Comparative Political Studies 41(4-5): 600-37.

Jackson, G. and Deeg, R. (2006). "How Many Varieties of Capitalism? Comparing the Comparative Institutional Analyses of Capitalist Diversity." MPIfG Discussion Paper 06/2. Cologne: Max Planck Institute for the Study of Societies.

Jakobi, A.P. and Martens, K. (2007). "Diffusion durch Internationale Organisationen: Die Bildungspolitik der OECD." In K. Holzinger, H. Jörgens and C. Knill, eds., Transfer, Diffusion und Konvergenz von Politiken Special issue Politische Vierteljahresschrift. 38: 247-70.

Lynch, L.M. (1994). Training and the Private Sector: International Comparisons. Chicago: University of Chicago Press. 
Mahoney, J. and Thelen, K. (2010). "A Theory of Gradual Institutional Change." In J. Mahoney and K. Thelen, eds., Explaining Institutional Change: Ambiguity, Agenda, and Power. Cambridge: Cambridge University Press, 1-37.

Mares, I. (2003). The Politics of Social Risk: Business and Welfare State Development. Cambridge: Cambridge University Press.

Martin, C.J. (2005). "Corporatism from the Firm Perspective." British Journal of Political Science 35(1): 127-48.

— Swank, D. (2004). "Does the Organization of Capital Matter? Employers and Active Labor Market Policy at the National and Firm Levels." American Political Science Review 98(4): 593-611.

(2008). "The Political Origins of Coordinated Capitalism." American Political Science Review 102(2): 181-98.

— Thelen, K. (2007). "The State and Coordinated Capitalism: Contributions of the Public Sector to Social Solidarity in Post-Industrial Societies." World Politics 60 (1): $1-36$.

Nilsson, A. (2008). "Vocational Education and Training in Sweden." Bulletin of Institute of Vocational and Technical Education 5/2008: 78-91.

Powell, J.J.W. and Solga, H. (2010). "Analyzing the Nexus of Higher Education and Vocational Training in Europe." Studies in Higher Education 35(6): 705-21.

__ (2011). "Why are Higher Education Participation Rates in Germany so Low? Institutional Barriers to Higher Education Expansion." Journal of Education and Work 24(1): 49-68.

Rothstein, B. (1992). "Labor-Market Institutions and Working-Class Strength." In K. Thelen and S. Steinmo, eds., Structuring Politics: Historical Institutionalism in Comparative Analysis. Cambridge: Cambridge University Press, 33-56.

Ryan, P. (2000). "The Institutional Requirements of Apprenticeship: Evidence from Smaller EU Countries." International Journal of Training and Development 4(1): 42-65.

Schmitter, P.C. and Streeck, W. (1999). "The Organization of Business Interests: Studying the Associative Action of Business in Advanced Industrial Societies." MPIfG Discussion Paper 99/1. Cologne: Max Planck Institute for the Study of Societies.

Stevens, M.L., Armstrong, E.A. and Arum, R. (2008). "Sieve, Incubator, Temple, Hub: Empirical and Theoretical Advances in the Sociology of Higher Education." Annual Review of Sociology 34: 127-51.

Streeck, W. (1992a). "On the Institutional Conditions of Diversified Quality Production." In W. Streeck and E. Matzner, eds., Beyond Keynesianism: The Socio-Economics of Production and Full Employment. London: Edward Elgar, 21-61.

- (1992b). Social Institutions and Economic Performance: Studies of Industrial Relations in Advanced Capitalist Economies. London: Sage.

- (1994). "Training and the New Industrial Relations: A Strategic Role for Unions?" In M. Regini, ed., The Future of Labour Movements. London: Sage, 250-69.

- (1996). "Lean Production in the German Automobile Industry: A Test Case for Convergence Theory." In R. Dore and S. Berger, eds., National Diversity and Global Capitalism. Ithaca, NY: Cornell University Press, 138-70.

(2009). Re-Forming Capitalism: Institutional Change in the German Political Economy. Oxford: Oxford University Press. 


\section{The Political Economy of Collective Skill Formation}

- (2010). "E Pluribus Unum? Varieties and Commonalities of Capitalism." MPIfG Discussion Paper 10/12. Cologne: Max Planck Institute for the Study of Societies.

— Schmitter, P.C. (1985). "Community, Market, State-and Associations? The Prospective Contribution of Interest Governance to Social Order." In W. Streeck and P.C. Schmitter, eds., Private Interest Government: Beyond Market and State. London: Sage, 1-29.

Swenson, P.A. (2002). Capitalists against Markets: The Making of Labor Markets and Welf are States in the United States and Sweden. Oxford: Oxford University Press.

Thelen, K. (2004). How Institutions Evolve: The Political Economy of Skills in Germany, Britain, the United States and Japan. Cambridge: Cambridge University Press.

- (2007). "Contemporary Challenges to the German Vocational Training System." Regulation \& Governance 1(3): 247-60.

- (2008). "Skill Formation and Training." In G. Jones and G. Zeitlin, eds., The Oxford Handbook of Business History. Oxford: Oxford University Press, 558-80.

— Kume, I. (2006). "Coordination as a Political Problem in Coordinated Market Economies." Governance 19(1): 11-42.

Trampusch, C. (2009). "Europeanization and Institutional Change in Vocational Education and Training in Germany and Austria." Governance 22(3): 369-95.

- (2010a). "Employers, the State, and the Politics of Institutional Change: Vocational Education and Training in Austria, Germany and Switzerland." European Journal of Political Research 49(4): 545-73.

- $(2010 b)$. "Co-evolution of Skills and Welfare in Coordinated Market Economies? A Comparative Historical Analysis of Denmark, the Netherlands, and Switzerland." European Journal of Industrial Relations 16(3): 197-220.

- (2010c). "The Politics of Institutional Change: Transformative and Self-Preserving Change in the Vocational Education and Training System in Switzerland." Comparative Politics 42(2): 187-206.

— Mach, A., eds. (2011). Switzerland in Europe. Continuity and Change in the Swiss Political Economy. London: Routledge.

Walkenhorst, H. (2008). "Explaining Change in EU Education Policy." Journal of European Public Policy 15(4): 567-87.

Wettstein, E. and Gonon, P. (2009). Berufsbildung in der Schweiz. Berne: hep.

Wolter, S.C., Muehlemann, S. and Schweri, J. (2006). "Why Some Firms Train Apprentices and Many Other Do Not." German Economic Review 7(3): 249-64. 